\title{
Pengaruh Kepemimpinan dan Sistem Penghargaan terhadap Kinerja Pegawai dengan Kepuasan Kerja sebagai Variabel Media
}

(Study Kasus di PT. Pendidikan Ganesha Operation Pematangsiantar)

\author{
Nancy Florida Siagian \\ Politeknik Bisnis Indonesia \\ siagiannancyflorida@gmail.com
}

\author{
Ambo Enre \\ Sekolah Tinggi Akuntansi Dan Manajemen Indonesia \\ amboenre@gmail.com \\ R. Elfrida Panjaitan \\ Politeknik Bisnis Indonesia \\ elfridapanjaitan34@yahoo.co.id
}

\begin{abstract}
The purpose of this study was to determine the effect of leadership and reward systems on Employee Performance with job satisfaction as a mediating variable. With a sample of 70 respondents. The tool used is a questionnaire. The results of this study are that leadership has a positive and significant effect on employee performance. The reward system has significant and significant effect on employee performance, leadership and reward systems have a positive and significant effect on job satisfaction, job satisfaction has a positive and significant effect on employee performance, and leadership, reward systems and job satisfaction has a positive and significant effect on employee performance. With the value of t calculated for leadership variable 2,278 and reward system 3,117 while for job satisfaction as mediation has a value of $t$ count equal to there is a value of 1,994 which means that the value of $t$ count has 'Sig' $<0,05 . R$ Square of 0.433, means that variations in employee performance can be explained by variations in leadership, reward systems and job satisfaction by $43.3 \%$ and the rest explained by other variations not examined.
\end{abstract}

Keywords Leadership, Reward System, Job Satisfaction and Employee Performance

\section{PENDAHULUAN}

Setiap instansi atau organisasi dalam menghadapi era globalisasi saat ini, akan menuntut karyawannya untuk meningkatkan kinerjanya. Tetapi upaya tersebut harus sejalan dengan peningkatan peran manajemen dalam melakukan kepemimpinan yang efektif. Kesuksesan atau kegagalan dalam pelaksanaan tugas di suatu perusahaan

dipengaruhi oleh kepemimpinan dan didukung oleh kapasitas perusahaan yang memadai, maka tujuan perusahaan akan terwujud. Sebaliknya kelemahan kepemimpinan merupakan salah satu sebab keruntuhan kinerja suatu perusahaan.

Sondang, P. Siagian (2005) mengatakan bahwa kepemimpinan adalah suatu proses pengembangan ide dan visi, yang selalu berada di dalam nilai-nilai yang mendukung oleh ide-ide dan visi tersebut, mempengaruhi orang lain dan membuat keputusan yang tepat terhadap manusia dan sumberdaya lainnya. 
Sistem penghargaan yang diarahkan pada pemenuhan kebutuhan individu dapat mendukung pada peningkatan efektivitas organisasi. Pendekatan peningkatan kepuasan dapat membantu membangun motivasi kerja, sistem kerja yang lebih efektif se-hingga menjamin sebuah penghargaan mempunyai nilai penting dalam pelaksanaan tugas secara efektif.

Sistem penghargaan yang diarahkan pada pemenuhan kebutuhan individu dapat mendukung pada peningkatan efektivitas organisasi. Pendekatan peningkatan kepuasan dapat membantu membangun motivasi kerja, sistem kerja yang lebih efektif sehingga menjamin sebuah penghargaan mempunyai nilai penting dalam pelaksanaan tugas secara efektif.

Kepuasan kerja (job satisfaction) adalah keadaan emosional yang menyenangkan atau tidak menyenangkan dimana para karyawan memandang pekerjaannya. Kepuasan kerja mencerminkan perasaan seseorang terhadap pekerjaannya. Hal ini tampak pada sikap positif karyawan terhadap pekerjaan dan segala sesuatu yang dihadapi dilingkungan kerjanya. Departemen personalia atau manajemen harus selalu memonitor, karena hal ini mempengaruhi sikap absensi, perputaran tenaga kerja, kepuasan kerja, dan masalah-masalah penting lainnya.

Pengukuran terhadap kinerja karyawan memiliki pengaruh yang penting bagi perkembangan karayawan. Pengukuran kinerja dapat digunakan untuk memasuki jenjang karir yang pantas sesuai dengan kinerja dan melihat kualitas karyawan apakah sesuai dengan tanggung jawabnya. Selain itu, penilaian kinerja karyawan juga diukur dengan tingkat kuantitas, kemampuan, sikap karyawan dan waktu penyelesaian pekerjaan yang diberikan. Faktor-faktor yang dapat mempengaruhi kinerja seorang karyawan yang bekerja di suatu perusahaan, antara lain: kepemimpinan, motivasi, kompensasi, disiplin, pembinaan, pengembangan karir, periode proyek yang terbatas, adanya sistem kontrak kerja, dan lain-lain.

Di tengah-tengah persaingan yang tajam dalam industri Bimbingan Belajar, pada tanggal 1 mei 1984 Ganesha Operation didirikan di kota bandung.

Latar belakang pendirian lembaga ini adalah adanya mata rantai yang putus dari link imformasi Sekolah Lanjutan Tingkat Atas dengan dunia Perguruan Tinggi Negeri (PTN). Posisi inilah yang di isi oleh Ganesha Operation untuk berfungsi sebagai jembatan dunia Sekolah Lanjutan Tingkat Atas terhadap dunia Perguruan Tinggi Negeri mengenai informasi jurusan PT (prospek dan tingkat persainganya), pemberian materi pelajaran yang sesuai dengan ruang lingkup bahan uji seleksi penerimaan mahasiswa baru dan pemberiaan metode-metode inovatif dan kreatif menyelesaikan soal-soal masuk PTN.

Menurut salah satu pegawai PT. Pendidikan Ganesha Operation Pematangsiantar, menyatakan "Sekitar 5 tahun terakhir ini para karyawan yang berprestasi baik, tidak pernah lagi diberi reward dari pimpinan dan sekarang sudah jarang adanya pemeriksaan ruangan proses blejar mengajar.

Keadaan yang demikian harus diantisipasi secepatnya karena jika seorang pegawai dan staff pengajar tidak puas biasanya mempunyai motivasi yang rendah. Akibatnya dalam bekerjapun mereka biasanya kurang bersemangat, malas, lambat bahkan bisa banyak melakukan kesalahan dan lain-lain hal yang bersifat negatif seperti kemangkiran, telat masuk kerja dan lai-lain.

Pimpinan Ganesha Operation Cabang Pematangsiantar melakukan beberapa cara untuk memotivasi para pegawai, seperti melakukan rapat setiap hari Senin untuk mengetahui program kerja yang akan dijalankan pegawai, dan apa hasil dari program kerja yang telah dijalankan pada minggu sebelumnya. Dengan demikian, pimpinan dapat memberikan

masukkan kepada para staff pengajar dan pegaawai program kerja apa yang perlum ditambah agar program kerja yang telah direncanakan para staff pengajar dan pegawai dapat berjalan dengan baik.

\section{Rumusan Masalah}

Dalam penelitian ini berdasarkan latar belakang yang ada maka pokok masalah yang dihadapi diuraikan sebagai berikut ini.

a. Bagaimana kepemimpinan berpengaruh terhadap kinerja pegawai?

b. Bagaimana sistem penghargaan berpengaruh terhadap kinerja kinerja pegawai? 
c. Bagaimana kepemimpinan dan sistem penghargaan secara bersama-sama berpengaruh terhadap kepuasan kerja?

d. Bagaimana kepuasan kerja berpengaruh terhadap kinerja pegawai?

e. Bagaimana kepemimpinan, sistem penghargaan berpengaruh terhadap kinerja pegawai yang dimediasi kepuasan kerja?

\section{Tujuan Penelitian}

1. Untuk mengetahui bagaimana pengaruh kepemimpinan terhadap kinerja pegawai.

2. Untuk mengetahui bagaimana pengaruh sistem penghargaan terhadap kinerja pegawai.

3. Untuk mengetahui pengaruh kepemimpinan dan sistem penghargaan secara bersama terhadap kepuasan kerja.

4. Untuk mengetahui pengaruh kepuasan kerja terhadap kinerja pegawai.

\section{LANDASAN TEORI}

Kepemimpinan merupakan bagian penting dari manajemen, karena kepemimpinan merupakan kemampuan yang dimiliki seseorang untuk mempengaruhi orang lain agar bekerja mencapai tujuan dan sasaran. Handoko (2003) mengemukakan bahwa kepemimpinan ialah kemampuan yang dimiliki seseorang untuk mempengaruhi orang lain agar bekerja mencapai tujuan dan sasaran.

Kepemimpinan dalam pengertian umum berarti menunjukkan suatu proses kegiatan seseorang dalam hal memimpin, membimbing, mempengaruhi atau mengontrol pikiran, perasaan dan tingkah laku terhadap orang lain yang berada di bawah pengawasannya. Menurut Davis (2000: 152), "kepemimpinan adalah proses mendorong, membantu orang lain untuk bekerja sama dengan antusias mencapai tujuan". Sedangkan menurut Malayu SP Hasibuan (2004), pengetahuan kepemimpinan adalah: "Cara seseorang pemimpin mempengaruhi bawahan agar mau bekerjasama dengan bekerja secara produktif untuk mencapai tujuan organisasi."

Penghargaan adalah ganjaran yang diberikan untuk memotivasi para karyawan. Penghargaan adalah insentif yang mengaitkan bayaran atas dasar untuk dapat meningkatkan produktivitas para karyawan guna mencapai keunggulan yang kompetitif (Simamora, 2004:514). Selanjutnya Miller (2002) menyebutkan bahwa dalam sistem imbalan terdapat struktur tugas dan prosedur secara luas yang memungkinkan organisasi untuk melakukan penambahan, penghapusan, atau penyesuaian segi-segi pekerja guna menambah ketertarikan bagi karyawan secara intrinsik. Dengan demikian, Miller memahami sistem imbalan tidak hanya berwujud promosi dan peningkatan gaji atas dasar kecakapan, tetapi bagaimana basis sistem ini dijamin.

Menurut Kreitner dan Kinicki $(2003 ; 271)$ kepuasan kerja adalah "suatu efektifitas atau respons emosional terhadap berbagai aspek pekerjaan”. Davis dan Newstrom (2000) mendeskripsikan "kepuasan kerja adalah seperangkat perasaan pegawai tentang menyenangkan atau tidaknya pekerjaan mereka". Menurut Robbins $(2003 ; 78)$ kepuasan kerja adalah "sikap umum terhadap pekerjaan seseorang yang menunjukkan perbedaan antara jumlah penghargaan yag diterima pekerja dan jumlah yang mereka yakini seharusnya mereka terima".

Kepuasan kerja merupakan respon afektif atau emosional terhadap berbagai segi atau aspek pekerjaan seseorang sehingga kepuasan kerja bukan merupakan konsep tunggal. Seseorang dapat relatif puas dengan salah satu aspek pekerjaan dan tidak puas dengan satu atau lebih aspek lainnya.

Menurut Simanjutak (2005), "Kinerja adalah tingkatan pencapaian hasil atas pelaksanaan tugas tertentu. Simanjuntak juga mengartikan kinerja individu sebagai tingkat pencapaian atau hasil kerja seseorang dari sasaran yang harus dicapai atau tugas yang harus dilaksanakan dalam kurun waktu tertentu". Foster dan Seeker (2001) menyatakan bahwa, "Kinerja adalah hasil yang dicapai seseorang menurut ukuran yang berlaku untuk pekerjaan yang bersangkutan". untuk mengukur kinerja organsiasi publik Dwiyanto (2007) menambah dua konsep lagi yaitu produktivitas dan kualitas layanan. Produktivitas adalah output yang dihasilkan oleh organisasi yaitu jenis layanan apa yang dihasilkan atau yang dilakukan oleh suatu organisasi. Sedangkan kualitas layanan dapat 
dilihat dari penilaian pengguna jasa atau masyarakat yaitu bagaimana tingkat kepuasan mereka terhadap layanan yang diberikan oleh organisasi.

\section{Hipotesis}

Berkenaan dengan masalah ini Arikunto (2006) menyatakan bahwa hipotesis dapat diartikan sebagai suatu jawaban yang bersifat sementara terhadap permasalahan penelitian sampai terbukti melalui data yang terkumpul.

Berdasarkan deskripsi dan kerangka berpikir yang telah diuraikan sebelumnya, maka dapat dirumuskan suatu hipotesis sebagai berikut :

1. Kepemimpinan berpengaruh positif dan signifikan terhadap Kinerja Pegawai.

2. Sistem Penghargaan berpengaruh positif dan signifikan terhadap Kinerja Pegawai.

3. Kepemimpinan dan Sistem Penghargaan berpengaruh positif dan signifikan terhadap Kepuasan Kerja.

4. Kepuasan Kerja berpengaruh positif dan signifikan terhadap Kinerja Pegawai.

5. Kepemimpinan dan Sistem Penghargaan bersama-sama berpengaruh positif dan signifikan terhadap Kinerja Pegawai yang dimediasi oleh Kepuasan Kerja.

\section{METODE PENELITIAN}

\section{Desain Penelitian}

Penelitian Ini didasarkan pada hubungan kasual yang bersifat sebab akibat, jadi ada variabel independen (variabel yang mempengaruhi), variabel dependen (variabel yang dipengaruhi), dan variabel mediasi (variabel yang mempengaruhi hubungan antara variabel independen dengan dependen).

\section{Instrumen Penelitian}

Penentuan skoring ilmiah secara umum berpedoman pada aturan Likert dan Gutman. Kedua metode ini memenuhi kaidah ilmiah dalam penentuan dan penilaian skoring suatu instrumen penelitian. Dalam hal ini penulis memakai metode Likert. Pendekatan dengan skala Likert digunakan untuk mengukur sikap, pendapat dan persepsi seseorang atau sekelompok orang tentang fenomena sosial.

Untuk analisis secara kuantitatif, maka altenatif jawaban tersebut dapat diberi skor dair nilai 1 sampai 5 sebagai berikut :

- Sangat Setuju (SS) di beri skor 5

- Setuju (S) di beri skor 4

- Netral (N) di beri skor 3

- Tidak Setuju (TS) di beri skor 2

- Sangat Tidak Setuju (STS) di beri skor 1

\section{Lokasi Dan Waktu Penelitian}

Untuk melakukan suatu penelitian tidak pernah terlepas dari tempat atau lokasi digunakan untuk mengumpulkan data atau informasi. Sesuai dengan judul yang dikemukakan sebelumnya, maka dalam pelaksanaan penelitian ini, penulis memilih lokasi atau tempat penelitian di PT. Pendidikan Ganesha Operation, Jalan Merdeka, Kota Pematangsiantar.

\section{Uji Normalitas Data}

Normalitas bertujuan untuk menguji apakah dalam model regresi, dependen variabel dan independent variabel keduanya mempunyai distribusi normal ataukah tidak. Model regresi yang baikadalah memiliki distribusi data normal atau mendekati normal (Imam Ghozali, 2006).

Mendeteksi dengan melihat penyebaran data (titik) pada sumbu diagonal dari grafik normal $P-P$ Plot. Dasar pengambilan keputusan: Jika data menyebar di sekitar garis diagonal dan mengikuti arah garis diagonal, atau grafik histogramnya menunjukkan pola distribusi normal, maka 
model regresi memenuhi asumsi normalitas. Jika data menyebar jauh dari garis diagonal dan atau tidak mengikuti arah garis diagonal, atau grafik histogram tidak menunjukkan pola distribusi normal, maka model regresi tidak memenuhi asumsi normalitas.

\section{Uji Hipotesis}

\section{a. Uji t}

Untuk menentukan tingkat signifikan secara parsial antara masing-masing variabel bebas dengan variabel terikat, maka hipotesis harus diuji-t pada taraf signifikan sebesar $\alpha=5 \%$ secara dua arah. Selanjutnya diambil keputusan, yaitu :

- Jika nilai signifikansi pengujian >0,05 $(\alpha=5 \%)$, maka Ho diterima dan Ha ditolak, sehingga hipotesis yang dirumuskan tidak terbukti kebenarannya.

- Jika nilai signifikansi pengujian < 0,05 $(\alpha=5 \%)$, maka Ho ditolak dan Ha diterima, sehingga hipotesis yang dirumuskan terbukti kebenarannya.

\section{b. Uji F}

Sehubungan dengan uji regresi linier berganda, uji hipotesis ditentukan dengan menggunakan uji F. Pengujian ini dilakukan untuk menentukan signifikan pengaruh variabel-variabel secara simultan terhadap variabel terikat. Pengujian ini akan membandingkan nilai signifikan dari hasil pengujian data dengan membandingkan nilai signifikan yang telah ditetapkan sebesar 0.05 atau $5 \%$.

\section{HASIL DAN PEMBAHASAN}

Dalam evaluasi data ini penulis akan melakukan pengujian hipotesis, baik secara partial ataupun secara simultan. Selanjutnya untuk mempermudah dalam evaluasi data ini, maka penulis mencari nilai-nilai yang dibutuhkan dengan menggunakan perangkat lunak komputer Program SPSS Vs. 22 for windows dengan hasil sebagai berikut :

\section{Uji Regresi Model- 1 dan Model-2}

Untuk menguji bagaimana pengaruh masing-masing variabel bebasnya secara sendiri-sendiri terhadap variabel terikatnya. Uji ini dapat dilakukan dengan mambandingkan $\mathrm{t}$ hitung dengan $\underline{\mathrm{t}}$ tabel atau dengan melihat kolom signifikansi pada masing-masing t hitung.

Tabel 1. Hasil Uji Regresi Model-1

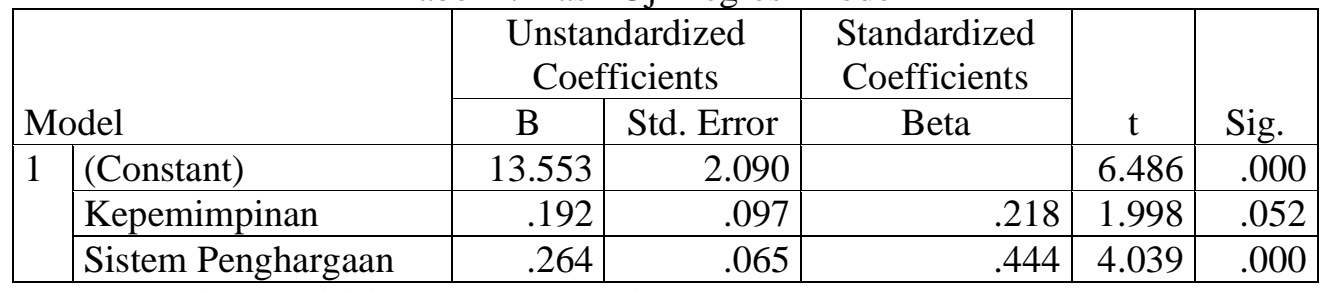

a. Dependent Variable: Kepuasan Kerja

Sumber : Hasil Penelitian-2018 (Data diolah)

Dari output 'Coefficients di atas nilai t hitung untuk variabel kepemimpinan adalah 1,998 dan untuk sistem penghargaan 4,039 sementara nilai t tabel (dilihat pada uji dua arah pada kolom 0,05 atau tarap 5\%) terdapat nilai 1,994 yang artinya nilai thitung kedua variabel lebih besar dari nilai $t$ tabel dan nilai 'Sig' Kepemimpinan 0,052 dan Sistem Penghargaan 0,000 yang artinya kedua variabel memiliki nilai 'Sig' $<0,05$, maka disimpulkan bahwa terdapat pengaruh yang signifikan antara Kepemimpinan (X1) dan Sistem Penghargaan (X2) terhadap Kepuasan Kerja (Z). 
Tabel 2. Hasil Uji Regresi Model-2

\begin{tabular}{|c|c|c|c|c|c|}
\hline \multirow[b]{2}{*}{ Model } & \multicolumn{2}{|c|}{$\begin{array}{l}\text { Unstandardized } \\
\text { Coefficients }\end{array}$} & \multirow{2}{*}{$\begin{array}{l}\text { Standardized } \\
\text { Coefficients } \\
\text { Beta }\end{array}$} & \multirow[b]{2}{*}{$\mathrm{t}$} & \multirow[b]{2}{*}{ Sig. } \\
\hline & $\mathrm{B}$ & Std. Error & & & \\
\hline 1 (Constant) & 4.189 & 4.220 & & -.993 & .325 \\
\hline Kepemimpinan & .359 & .158 & .238 & 2.278 & .026 \\
\hline Sistem Penghargaan & .360 & .115 & .352 & 3.117 & .003 \\
\hline Kepuasan Kerja & .398 & .193 & .232 & 2.056 & .044 \\
\hline
\end{tabular}

a. Dependent Variable: Kinerja Pegawai

Sumber : Hasil Penelitian-2018 (Data diolah)

Dari output 'Coefficients di atas nilai thitung untuk variabel kepemimpinan 2,278 dan sistem penghargaan 3,117 sementara untuk kepuasan kerja sebagai mediasi memiliki nilai t hitung sebesar 2,056 jika nilai t hitung dibandingkan dengan nilai $t$ tabel (dilihat pada uji dua arah pada kolom 0,05 atau tarap 5\%) terdapat nilai 1,994 yang artinya nilai t hitung kedua variabel independen dan mediasi lebih besar dari nilai t tabel dan nilai 'Sig' kepemimpinan 0,026, sistem penghargaan 0,003 dan kepuasan kerja 0,044 yang artinya semua

variabel memiliki 'Sig' $<0,05$, maka disimpulkan bahwa terdapat pengaruh yang signifikan antara Kepemimpinan dan Sistem Penghargaan terhadap kinerja yang dimediasi oleh Kepuasan Kerja.

\section{Koefisien Determinasi $\left(\mathbf{R}^{2}\right)$}

Koefisien determinasi mengukur seberapa besar pengaruh variabel independen secara keseluruhan terhadap naik turunnya variasi nilai variabel dependen.

Tabel 3. Koefisien Determinasi

\begin{tabular}{|l|c|c|cr|}
\hline & & & \\
Model & $\mathrm{R}$ & $\mathrm{R}$ Square & Adjusted R Square \\
\hline 1 & $.658^{\mathrm{a}}$ & .433 & \\
\hline
\end{tabular}

Sumber : Hasil Penelitian-2018 (Data diolah)

Pada output Model Summary nilai R Square sebesar 0,433, berati variasi Kinerja Pegawai dapat dijelaskan oleh variasi Pengawasan, Sistem Penghargaan dan Kepuasan Kerja sebesar 43,3 \% dan selebihnya dijelaskan oleh variasi lain yang tidak diteliti.

\section{Uji F}

Uji F digunakan untuk mengetahui pengaruh variabel bebas secara bersama-sama (simultan) terhadap variabel terikat. Signifikan berarti hubungan yang terjadi dapat berlaku untuk populasi.

Tabel 4.4. Hasil Uji F

\begin{tabular}{|l|r|r|r|r|c|}
\hline \multicolumn{5}{|c|}{ ANOVA $^{\mathrm{a}}$} \\
\hline Model & $\begin{array}{c}\text { Sum of } \\
\text { Squares }\end{array}$ & \multicolumn{1}{c|}{ df } & $\begin{array}{c}\text { Mean } \\
\text { Square }\end{array}$ & \multicolumn{1}{c|}{ F } & \multicolumn{1}{c|}{ Sig. } \\
\hline Regression & 240.015 & 3 & 80.005 & $\begin{array}{r}16.78 \\
0\end{array}$ & $.000^{\mathrm{b}}$ \\
\hline Residual & 314.685 & 66 & 4.768 & & \\
\hline Total & 554.700 & 69 & & & \\
\hline a. Dependent Variable: Kinerja Pegawai \\
\hline
\end{tabular}


b. Predictors: (Constant), Kepuasan Kerja, Kepemimpinan, Sistem

Penghargaan

Sumber : Hasil Penelitian-2018 (Data diolah)

Apabila Nilai $\mathrm{F}$ hitung lebih besar dari $\mathrm{F}$ tabel maka dapat disimpulkan bahwa terdapat pengaruh yang signifikan. Dari tabel diatas, nilai $\mathrm{F}$ hitung $>\mathrm{F}$ tabel, dimana nilai $\mathrm{F}$ Tabel 3,128 $(16,780>3,128)$. Maka dapat disimpulkan terdapat pengaruh yang signifikan antara kepemimpinan dan sistem penghargaan terhadap kinerja pegawai yang di mediasi oleh kepuasan kerja.

Ringkasan hasil uji regresi medel-1 dan model-2 dapat menjelaskan hasil hipotesis pada penelitian ini sebagai berikut:

\section{Kepemimpinan Berpengaruh Positif Terhadap Kinerja Pegawai}

Pada tabel 4.2 kepemimpinan memiliki nilai 'Sig' sebesar 0,026. terhadap kinerja pegawai, nilai 'Sig' $t$ lebih kecil dari taraf signifikansi pada taraf 0,05 atau $5 \%(0,026<0,05)$. Hal ini menjawab bahwa pertanyaan pada hipotesis 1 diterima dan menyatakan kepemimpinan signifikan dan berpengaruh positif terhadap kinerja pegawai.

\section{Sistem Penghargaan Berpengaruh Positif Terhadap Kinerja Pegawai}

Pada tabel 4.2 sistem penghargaan memiliki nilai 'Sig' sebesar 0,003 terhadap kinerja pegawai, nilai 'Sig' t lebih kecil dari taraf signifikansi pada taraf 0,05 atau $5 \%(0,003<0,05)$. Hal ini menjawab bahwa pertanyaan pada hipotesis 1 diterima dan menyatakan sistem penghargaan signifikan dan berpengaruh positif terhadap kinerja pegawai.

\section{Kepemimpinan Dan Sistem Penghargaan Secara Bersama-Sama Berpengaruh Positif Terhadap Kepuasan Kerja}

Pada table 4.2 kepemimpinan dan sistem penghargaan memiliki nilai 'Sig' masing-masing sebesar 0,052 dan 0,000 terhadap kepuasan kerja nilai 'Sig' kedua variabel tersebut lebih kecil dari taraf signifikansi pada taraf 0,05 atau $5 \%(0,052$ dan $0,000<0,05)$. Hal ini menjawab bahwa pertanyaan pada hipotesis 3 diterima dan dinyatakan kepemimpinan dan sistem penghargaan signifikan dan bersama sama berpengaruh positif terhadap kepuasan kerja.

\section{Kepuasan Kerja Berpengaruh Positif Terhadap Kinerja Pegawai}

Pada tabel 4.2 kepuasan kerja memiliki nilai 'Sig' sebesar 0, terhadap kinerja pegawai nilai 'Sig' tersebut lebih kecil dari taraf signifikansi pada taraf 0,044 atau 5\% $(0,044<0,05)$. Hal ini menjawab bahwa pertanyaan pada hipotesis 4 diterima dan dinyatakan kepuasan kerja signifikan dan berpengaruh positif terhadap kinerja pegawai.

\section{Kepemimpinan Dan Sistem Penghargaan Secara Bersama Sama Berpengaruh Positif Terhadap Terhadap Kinerja Pegawai Yang Dimediasi Oleh Kepuasan Kerja}

Pada tabel 4.2 kepemimpinan dan Sistem penghargaaan dan kepuasan kerja memiliki nilai 'Sig' masing-masing sebesar 0,026, 0,003 dan 0,044 terhadap kinerja pegawai nilai 'Sig' ketiga variabel tersebut lebih kecil dari taraf signifikansi pada taraf 0,05 atau 5\% $(0,026,0,001$ dan 0,044 $<0,05)$. Hal ini menjawab bahwa pertanyaan pada hipotesis 5 diterima dan dinyatakan kepemimpinan dan sistem penghargaan signifikan dan bersama sama berpengaruh positif terhadap kinerja pegawai yang dimediasi oleh kepuasan kerja.

\section{KESIMPULAN} berikut :

Dari pembahasan penelitian yang telah diuraikan, maka dapat ditarik kesimpulan sebagai 
1. Terdapat pengaruh yang positf dan signifikan antara Kepemimpinan terhadap Kinerja Pegawai PT. Pendidikan Ganesha Operation Pematangsiantar, dengan demikian Ha diterima dan Ho diterima.

2. Terdapat pengaruh yang signifikan antara Sistem Penghargaan terhadap Kinerja Pegawai PT. Pendidikan Ganesha Operation Pematangsiantar, dengan demikian Ha diterima dan Ho diterima.

3. Terdapat pengaruh yang signifikan antara Kepemimpinan dan Sistem Penghargaan terhadap Kinerja Pegawai PT. Pendidikan Ganesha Operation Pematangsiantar, dengan demikian Ha diterima dan Ho diterima.

4. Terdapat pengaruh yang signifikan antara Kepuasan Kerja terhadap Kinerja Pegawai PT. Pendidikan Ganesha Operation Pematangsiantar, dengan demikian Ha diterima dan Ho diterima.

5. Terdapat pengaruh yang signifikan antara Kepemimpinan dan Sistem Penghargaan terhadap Kinerja Pegawai PT. Pendidikan Ganesha Operation Pematangsiantar yang dimediasi oleh motivasi, dengan demikian Ha diterima dan Ho diterima.

\section{Saran}

Dari kesimpulan diatas, untuk mengantisipasi hal tersebut dan untuk mencapai maksud dan tujuan peningkatan Kinerja Pegawai PT. Pendidikan Ganesha Operation Pematangsiantar, maka disarankan sebagai berikut:

1. Sehubungan dengan peningkatan kinerja pegawai, pemimpin hendaknya dapat memotivasi dan memberi kesempatan seluas-luasnya untuk dapat bekerja dan berkarya sesuai dengan kemampuan yang telah mereka miliki.

2. Dikarenakan terdapat pengaruh antara kepuasan kerja terhadap Kinerja Pegawai PT. Pendidikan Ganesha Operation Pematangsiantar, maka harus memperhatikan setiap kritik dan saran. Dalam hal ini tidak perlu meningkatkan sikap rasional dalam berpikir dan tidak mendahulukan emosi pribadi sehingga suasana kerja lebih kondusif.

3. Keikutsertaan Masyarakat dalam mendukung program pemerintah mencerdaskan anak bangsa, PT. Pendidikan Ganesha Operation Pematangsiantar diharapkan berperan penting dalam pengembangan karakter bangsa, hal ini disebabkan pegawai beserta tenaga pengajar PT. Pendidikan Ganesha Operation Pematangsiantar memegang peranan penting dalam pengembangan potensi peserta didik. Karena peran pegawai beserta tenaga pengajar PT. Pendidikan Ganesha Operation Pematangsiantar selain sebagai pendidik adalah sebagai pembimbing yang memberikan bantuan kepada peserta didik dalam pemahaman dan pengarahan diri.

\section{REFERENSI}

Arikunto, Suharsimi. 2006. Prosedur Penelitian Suatu Pendekatan Praktik. Bina Aksara. Yogyakarta.

Davis, Keith dan Newstrom. 2000. Perilaku Dalam Organisasi. Edisi ketujuh. Penerbit Erlangga. Jakarta.

Dwiyanto, A.,Dkk. 2007. Kinerja Tata Pemerintahan Daerah di Indonesia. PSKK.UGM. Yogyakarta.

Ghozali, Imam. 2006. Aplikasi Analisis Multivariate Dengan Program SPSS. Cetakan Keempat. Badan Penerbit Universitas Diponegoro. Semarang.

Handoko, T. Hani. 2003. Manajemen Sumber Daya Manusia. Salemba Empat. Bandung.

Kreitner, Robert dan Kinicki, Angelo. 2003. Perilaku Organisasi, Terjemahan: Erly Suandy, Edisi Pertama. Salemba Empat. Jakarta.

Robbins. 2003. Organizational Behaviour. Tenth Edition. Edisi Bahasa Indonesia. PT. Indeks Kelompok Gramedia. Jakarta.

Simanjuntak, Payaman J. 2005. Manajemen dan Evaluasi Kinerja. FE UI. Jakarta. 
Jurnal Ekonomi \& Ekonomi Syariah Vol 2 No 2, Juni 2019

E-ISSN : 2599-3410 | P-ISSN : 2614-3259

DOI : https://doi.org/10.36778/jesya.v3i1.130

Simamora, Henry. 2004. Manajemen Sumber Daya Manusia. Edisi Ketiga, Cetakan Pertama. Penerbitan STIE YKPN. Yogyakarta.

Sondang, P. Siagian. 2005. Organisasi, Kepemimpinan dan Perilaku Organisasi. CV Haji Masagung. Jakarta.

Stoner, James, A.F. 2002. Perilaku Dalam Organisasi. Jilid Kedua. Edisi Ketujuh Erlangga. Jakarta.

Wibowo. 2007. Manajemen Kinerja. PT. Raja Grafindo Persada. Jakarta. 